See Article page e277.

\section{Commentary: The stem cell bridge: Forging a path above cold storage}

Jason J. Han, MD, Amit Iyengar, MD, and Pavan Atluri, MD

Heart transplantation remains the gold standard of treatment for patients with end-stage heart failure, with a median survival of 13 years. ${ }^{1}$ However, owing to the scarce and stagnant supply of donor organs in the United States over the past 3 decades, patients continue to experience significant mortality on the waiting list. Although one of the significant limitations is supply, the other is inherent to the current standard of donor organ preservation-cold static storage-which poses temporal and geographic challenges to facilitating safe, equitable organ allocation. ${ }^{2,3}$ The risk of primary graft failure and death correlates with increasing duration of ischemia. ${ }^{4}$

Mesenchymal stem cell (MSC) therapy has held promise for regenerative cardiac therapies for decades. In tandem with small clinical trials demonstrating the safety and limited efficacy of MSCs in improving cardiac function after ischemic injury or cardiac surgery, the mechanisms behind these cellular therapies are beginning to be explored. ${ }^{5}$ More so than cell engraftment and growth from exogenous cells, paracrine pathways and the release of extracellular nanoparticles have recently been highlighted as important mechanisms of action of MSCs. ${ }^{6}$ The translational potential of this finding is currently under active investigation across various domains.

It is at this opportune moment that Wang and colleagues ${ }^{7}$ share their insights on the role of MSC-derived therapy in reducing injury from prolonged cold ischemia in an ex vivo mouse heterotopic transplantation model. MSC

\footnotetext{
From the Division of Cardiovascular Surgery, Department of Surgery, University of Pennsylvania, Philadelphia, Pa.

Disclosures: The authors reported no conflicts of interest.

The Journal policy requires editors and reviewers to disclose conflicts of interest and to decline handling or reviewing manuscripts for which they may have a conflict of interest. The editors and reviewers of this article have no conflicts of interest.

Received for publication Sept 9, 2020; revisions received Sept 9, 2020; accepted for publication Sept 10, 2020; available ahead of print Sept 14, 2020.

Address for reprints: Pavan Atluri, MD, Division of Cardiovascular Surgery, Department of Surgery, Hospital of the University of Pennsylvania, 3400 Spruce St, 6 Silverstein Pavilion, Philadelphia, PA (E-mail: Pavan.Atluri@uphs.upenn.edu).

J Thorac Cardiovasc Surg 2022;163:e293-4

$0022-5223 / \$ 36.00$

Copyright $(2020$ by The American Association for Thoracic Surgery

https://doi.org/10.1016/j.jtcvs.2020.09.038
}

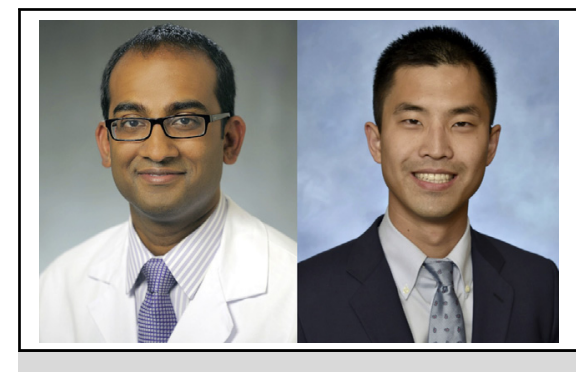

Pavan Atluri, MD, and Jason J. Han, MD

CENTRAL MESSAGE

Comprehensive mesenchymal stem cell-derived secretome may enhance donor organ viability in heart transplantation.

conditioned medium (CM), designed to include a comprehensive MSC "secretome," was delivered as an adjunct to standard preservation solution and demonstrably improved donor heart recovery after 6 hours of ischemic cold, static storage. These observations were consistent across hemodynamic and histological analyses and were partially reversed by concomitant use of an exosomerelease inhibitor. Hearts in the intervention arms also returned to spontaneous contractility more readily on reperfusion.

The study by Wang and colleagues is significant in that it is one of the first studies to highlight this therapy in a cold ischemia model. Although intuitively, this may follow previous work surrounding ischemia-reperfusion injury and ischemic cardiomyopathies, the authors are to be commended for helping to bring MSC therapy into the conversation surrounding donor organ preservation and transplantation. The authors postulate exosomal transfer of microRNA from MSCs to donor heart as a possible mechanism, which has significant implications, as exosomes are highly conducive to clinical applications and can be relatively easily prepared, stored, and used for therapy.

\section{References}

1. Christie JD, Edwards LB, Kucheryavaya AY, Aurora P, Dobbels F, Kirk R, et al The registry of the International Society for Heart and Lung Transplantation: twenty-seventh official adult lung and heart-lung transplant report-2010. J Heart Lung Transplant. 2010;29:1104-18.

2. Mitropoulos FA, Odim J, Marelli D, Karandikar K, Gjertson D Ardehali A, et al. Outcome of hearts with cold ischemic time greater 
than 300 minutes: a case-matched study. Eur J Cardiothorac Surg. 2005; 28:143-8.

3. Russo MJ, Chen JM, Sorabella RA, Martens TP, Garrido M, Ryan R, et al. The effect of ischemic time on survival after heart transplantation varies by donor age: an analysis of the united network for organ sharing database. J Thorac Cardiovasc Surg. 2007;133:554-9.

4. Young JB, Hauptman PJ, Naftel DC, Ewald G, Dec GW, Taylor DO, et al. Determinants of early graft failure following cardiac transplantation, a 10-year, multiinstitutional, multivariable analysis. J Heart Lung Transplant. 2011;20:212.
5. Angoulvant D, Ivanes F, Ferrera R, Matthews PG, Nataf S, Ovize M, et al. Mesenchymal stem cell-conditioned media attenuates in vitro and ex vivo myocardial reperfusion injury. J Heart Lung Transplant. 2011;30:95-102.

6. Gnecchi M, He H, Olin D, Liang OD, Melo LG, Morello F, et al. Paracrine action accounts for marked protection of ischemic heart by Akt-modified mesenchymal stem cells. Nat Med. 2005;11:367-8.

7. Wang M, Yan L, Li Q, Yang Y, Turrentine M, March K, et al. Mesenchymal stem cell secretions improve donor heart function following ex vivo cold storage. $J$ Thorac Cardiovasc Surg. 2022;163:e277-92.
See Article page e277.

\section{Commentary: The dilemma of donor heart cold storage: Are stem cell extracellular vesicles the answer?}

\author{
Leora B. Balsam, MD
}

Many donor-specific variables affect the feasibility and outcomes of heart transplantation. The ability of a donor heart to tolerate only a short period of cold ischemia has direct implications on when, where, and how donor hearts are procured. Strategies to extend the period of cold storage have been proposed, with focus on mitigating ischemic damage to the donor heart. These include modifying the conditions of cold storage by adding protective agents to the storage solution.

Wang and colleagues ${ }^{1}$ describe a novel way to extend the period of cold storage in an experimental model of heart transplantation. The additives to the storage solution are extracellular vesicles (EVs). EVs are carriers of bioactive proteins and nucleic acids that are involved in intercellular communication. The 3 main types of EVs, apoptotic bodies,

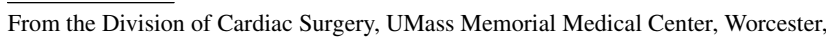
Mass.

Disclosures: The author reported no conflicts of interest.

The Journal policy requires editors and reviewers to disclose conflicts of interest and to decline handling or reviewing manuscripts for which they may have a conflict of interest. The editors and reviewers of this article have no conflicts of interest.

Received for publication Sept 12, 2020; revisions received Sept 12, 2020; accepted for publication Sept 14, 2020; available ahead of print Sept 18, 2020.

Address for reprints: Leora B. Balsam, MD, Division of Cardiac Surgery, UMass Memorial Medical Center, University Campus, 55 Lake Ave N, Worcester, MA 01655 (E-mail: leora.balsam@umassmemorial.org).

J Thorac Cardiovasc Surg 2022;163:e294-5 0022-5223/ $\$ 36.00$

Copyright $₫ 2020$ Published by Elsevier Inc. on behalf of The American Association for Thoracic Surgery

https://doi.org/10.1016/j.jtcvs.2020.09.048
Check for updates

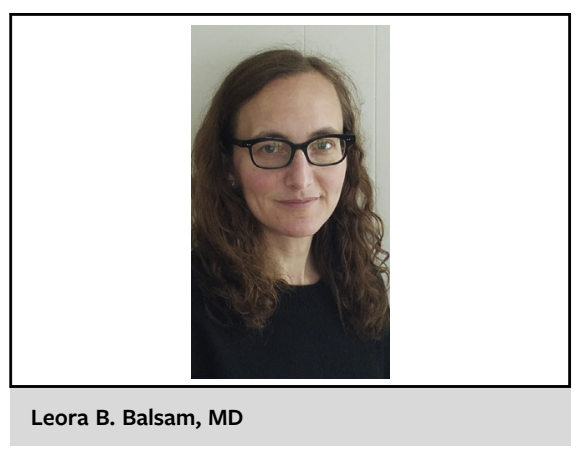

CENTRAL MESSAGE

The addition of secreted factors

from mesenchymal stem cells

mitigates donor heart injury after

prolonged cold storage in an

experimental model of heart

transplantation.

microvesicles, and exosomes, are differentiated based on size, contents, and surface markers. ${ }^{2}$

Wang and colleagues ${ }^{1}$ use cultured mesenchymal stem cells (MSCs) as the cell source for EVs in their model. The secretory products of the MSCs are released into the medium in which they are cultured, creating conditioned medium. They use a purification process to isolate predominantly exosomes; however, their methodology allows for contamination with microvesicles. The purified EVs (mixture of exosomes and microvesicles) are a cell-free preparation; when considering how one might translate this experimental work clinically, this is an important feature because issues related to immunogenicity or tumor formation from exogenous stem cells is avoided.

MSCs are of significant interest in regenerative medicine due to their plasticity (ie, ability to differentiate into numerous cell types depending on the microenvironment) and paracrine effects. In experimental models of 